\title{
Emerald Insight
}

\section{Structural Survey}

Research into practice: Malatya solar housing

Fikret Okutucu Ahmet Kochan Yusuf Yildiz Sengul Oymen Gur

\section{Article information:}

To cite this document:

Fikret Okutucu Ahmet Kochan Yusuf Yildiz Sengul Oymen Gur, (2010),"Research into practice: Malatya solar housing", Structural Survey, Vol. 28 Iss 5 pp. 420 - 439

Permanent link to this document:

http://dx.doi.org/10.1108/02630801011089191

Downloaded on: 14 December 2016, At: 04:11 (PT)

References: this document contains references to 19 other documents.

To copy this document: permissions@emeraldinsight.com

The fulltext of this document has been downloaded 994 times since 2010*

\section{Users who downloaded this article also downloaded:}

(2005),"Cost savings by application of passive solar heating", Structural Survey, Vol. 23 Iss 2 pp. 111-130 http://dx.doi.org/10.1108/02630800510593684

(2015),"Sustainable energy management: Solar energy and thermal storage technologies in two Mediterranean countries", Management of Environmental Quality: An International Journal, Vol. 26 Iss 5 pp. 764-790 http://dx.doi.org/10.1108/MEQ-06-2013-0063

Access to this document was granted through an Emerald subscription provided by emerald-srm:549085 []

\section{For Authors}

If you would like to write for this, or any other Emerald publication, then please use our Emerald for Authors service information about how to choose which publication to write for and submission guidelines are available for all. Please visit www.emeraldinsight.com/ authors for more information.

\section{About Emerald www.emeraldinsight.com}

Emerald is a global publisher linking research and practice to the benefit of society. The company manages a portfolio of more than 290 journals and over 2,350 books and book series volumes, as well as providing an extensive range of online products and additional customer resources and services.

Emerald is both COUNTER 4 and TRANSFER compliant. The organization is a partner of the Committee on Publication Ethics (COPE) and also works with Portico and the LOCKSS initiative for digital archive preservation.

*Related content and download information correct at time of download. 
SS

28,5

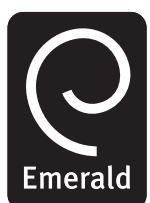

Structural Survey Vol. 28 No. 5,2010 pp. $420-439$ (C) Emerald Group Publishing Limited 0263-080X

DOI $10.1108 / 02630801011089191$

\section{Research into practice: Malatya solar housing}

Fikret Okutucu

Solar Energy Institute, EGE University, Bornova, Turkey

Ahmet Kochan

Faculty of Architecture and Engineering, Cukurova University, Adana, Turkey

Yusuf Yildiz

Department of Architecture, Izmir Institute of Technology, Urla, Turkey, and

Sengul Oymen Gur

Faculty of Architecture, Karadeniz Technical University, Trabzon, Turkey

\begin{abstract}
Purpose - The purpose of this research is to discover the underlying reasons for the failure of solar energy architecture in Turkey in order to be able suggest methods of improving it in Turkey and worldwide.

Design/methodology/approach - The methodology employed in this research is on-site observations of Turkish solar houses built with respect to the details of their application, and depiction of heat gains provided with applied solar measures, and to compare them with an ideal gauge to determine the deficiencies involved in applications.

Findings - The investigations discovered that various buildings under consideration share several errors. In order of importance, these items are: faulty applications, erroneous choice of methods and lack of precautions in the summer.

Practical implications - The practical implications of the study are that measures must be taken to prevent heat loss during winter nights; outer walls with a resistance to heat transmission of $\mathrm{u}=$ $1 \mathrm{~W} / \mathrm{m} 2 \mathrm{~K}$ would have been preferred rather than ordinary old-fashioned Trombe walls; in order to prevent overheating the surfaces of the sunspaces, Trombe walls and air collectors contacting the outer environment need to be made movable or pliable to avoid sinking of heated air into the sunspace.

Social implications - The social implication of the study is that only continued exploration into solar energy use via exemplary practice may encourage adoption of these systems by society itself.

Originality/value - The value of the research resides in translating knowledge gained from previous solar projects into design aspects which are expected to avoid these errors and deficiencies, demonstrated herein through Malatya solar housing, from which everyone involved in passive solar house design may benefit.
\end{abstract}

Keywords Solar power, Housing, Architecture

Paper type Research paper

\section{Introduction}

Buildings require two groups of expenditures. The first group is for design and construction, and the second is for usage and maintenance. While financers and developers provide the funding for the first group, users are responsible for the second group's funding.

Generally, the developers and users of social housing are different parties with different, mostly contradictory, interests. Developers and constructors aspire for more 
profit with less expenditure. Thus, maintenance and management expenses involving the usage of buildings are not usually taken into consideration by developers. Ultimately, users are responsible for expenditures arising from heating, ventilation, renovation, etc.

The goal of this article is to identify and substantiate ways of cutting energy expenditures via architectural design for the benefit of building users.

After the 1973 oil crisis, an eagerness to build with greater energy efficiency surfaced in the architectural industry, especially in Central Europe. Early in the 1980s, universities began constructing experimental houses and buildings heated by solar energy. The forerunners in Turkey were:

- Middle East Technical University's (METU) solar house (Turan et al., 1981), a one storey building with an area of $81 \mathrm{~m}^{2}$;

- Cukurova University's Solar House (Altun, 1982), a one storey building with an area of $100 \mathrm{~m}^{2}$; and

- Aegean University's (AU) Solar Energy Institute (Atagündüz, 1989), a three storey building with a total area of $2,700 \mathrm{~m}^{2}$.

Reports from the involved individuals and institutions revealed below-expected performance efficiency results for the aforementioned buildings (Turan et al., 1981; Altun, 1982; Tan, 1993; Atagündüz, 1989). Before evaluating these groundbreaking buildings, it will be useful to point out the particular difficulties in using solar energy for heating interiors.

As mentioned above, the producers and users of such buildings have different interests: the party involved in production is motivated by making a profit. Therefore, they do not bother spending money on heat-insulating materials or passive solar energy investments; they are not concerned with expenditures that might arise during use. Arguably, this might prevent energy efficient buildings from proliferating throughout Turkey and the rest of the world.

In addition, governments in Turkey have promulgated the selling of natural gas as a condition of signing an agreement between Turkey and Russia in the late 1990s, pressured by the promise of "constant payments irrelevant of the amount of use". Thus, governments pump high percentages of profits from the imported natural gas (49 per cent state tax) and electricity (65 per cent state tax) sold to their own citizens into the national treasury (Aydan, 2010). In other words, governments profit from of their own people instead of contributing to the reduction of energy consumption. Additionally, because the building laws and regulations in effect in the country were also impeding the realisation of designing and building with such new concepts as energy efficiency, architects benignly adopted the employment of exhaustible energy sources and evaded the burden of learning and applying sustainable new methods.

Successive governments (the 59th and 60th) have had to adopt new regulations to enforce the construction of these so-called energy efficient buildings despite the economic difficulties endured in the country. Because these buildings have failed to meet expectations, public trust in solar energy science has waned considerably.

Under these conflicting and confusing circumstances, it is difficult to foresee a future for passive solar energy systems in Turkey, where the solar energy potential is sufficient for heating residential buildings in many regions (Table I) (Özdeniz, 1984).
Malatya solar housing

421 
SS
28,5

422

The only way to encourage continued exploration into solar energy use is by adoption of these systems by society itself.

Nevertheless, the most important obstacle in convincing architects to build using energy efficient concepts is the lack of a successful example to pave the way for an increasing number of applications.

In 1995, the first author designed and built Guzelbahce Solar House in the hope of providing such an example (Okutucu, 2007). This house, which is two storeys and has a net usage area of $146 \mathrm{~m}^{2}$, is heated by passive solar energy. Over a total of five years its average heat expenditure per heating season was 150 litres of fuel oil (Okutucu, 2007), which is exemplary compared with a non-solar, ordinary house of the same net usage area (average consumption of 1,800 litres of fuel oil). The understanding, experience and results obtained from this project were later utilised in the Malatya Solar House, designed by the first author and explained in full detail below. To ensure success in the Malatya Solar House, the solar buildings erected previously in the country were examined and interpreted from the point of view of construction details and energy savings.

One characteristic of scientific research results, reports and theses is that they use unambiguous language. One reason for this is to establish the grounds and arguments from which the conclusions are derived. This characteristic has the effect of reinforcing the dominant knowledge models such as "the scientific method", "empirical methods", etc. (Ackoff et al., 1962; Feyerabend, 1975, 1987). However, these models come from disciplines whose aims and objectives may differ from those in practice. Practice consists of the application of scientifically gathered information in real-life situations where the information is manipulated by a certain knowledge conditional with varying problems and setbacks fabricated by the concrete situations of the actual context.

There is not much discussion in the literature about interpreting practical results. Although research results of scientific research and results of practical applications cannot be compared along the same decisive factors, an apposite provisional tool for tracing the progress of the application of solar buildings is devised here.

The interpretative tool employed in the analyses of the constructed solar buildings is as follows:

(1) calculate the percentage of energy gain of the building in total energy need per season;

(2) analyse the project in terms of precautions taken for different seasons; and

(3) check the structural integrity necessary for heat gains and prevention of heat loss.

Table I.

Geographical coordinates and climatic data of some cities in Turkey

\begin{tabular}{|c|c|c|c|c|c|c|c|}
\hline City & $\begin{array}{l}\text { Latitude } \\
(\mathrm{N})\end{array}$ & $\begin{array}{l}\text { Longitude } \\
\text { (E) }\end{array}$ & $\begin{array}{l}\text { Altitude } \\
\text { (m) }\end{array}$ & $\begin{array}{c}\text { Sunshine } \\
\text { period mean } \\
\text { of January } \\
\text { (h/day) }\end{array}$ & $\begin{array}{c}\text { Total } \\
\text { sunshine } \\
\text { mean of } \\
\text { January } \\
\left(\mathrm{MJ} / \mathrm{m}^{2} \text { day) }\right.\end{array}$ & $\begin{array}{l}\text { Humidity } \\
\text { (07:00) mean } \\
\text { of January (\%) }\end{array}$ & $\begin{array}{c}\text { Humidity } \\
\text { (14:00) mean } \\
\text { of January (\%) }\end{array}$ \\
\hline Adana & 37.00 & 35.16 & 27 & 4.8 & 5 & 75 & 50 \\
\hline Izmir & 38.25 & 27.08 & 29 & 4.2 & 4.3 & 82 & 70 \\
\hline Ankara & 39.57 & 32.54 & 891 & 3.6 & 5 & 85 & 70 \\
\hline Malatya & 38.21 & 38.18 & 998 & 4.4 & 4.6 & 80 & 72 \\
\hline \multicolumn{8}{|c|}{ Source: Özzdeniz (1984) } \\
\hline
\end{tabular}




\section{Analyses and assessment}

Institutes responsible for the construction of these solar houses such as the Ministry of Housing and the High Committee for the Development and Management of Electrical housing

Energy and Resources have provided reports showing energy the gains of each building (Turan et al., 1981; Altun, 1982; Tan, 1993; Atagündüz, 1989; Karakoc, 2006). Critical analysis and assessment of the building details were performed via direct, on-site observations by the authors of this article. These analyses on solar buildings constructed in Turkey discovered that various buildings under consideration share several errors. In order of importance, these items are elaborated as follows:

- Faulty applications - No measures are taken to prevent heat loss during winter nights in regards to large, South-facing glass façades built for transferring solar energy into heat. One solution would have been to use double glass on the side that faces the sun and contacts the interior space. Another solution would have been to place a heat-insulated sliding lid or a roller blind facing the sunspace in front of this glass wall enveloping a cavity of $5 \mathrm{~cm}$.

- Erroneous choice of methods - Rather than employing an ordinary old-fashioned Trombe wall (Kiraly, 1984), the performance of which is half that of a heat-insulated outer wall with a resistance to heat transmission of $u=1 \mathrm{~W} / \mathrm{m}^{2} \mathrm{~K}$, heat-insulated outer walls would have been preferred. At the 38th parallel in January, a Trombe wall and a sunspace (the glass house between the Trombe wall and the outer glass surface) can only transfer heat from solar energy for about three to four hours. During the other 20-21 hours of each day, a Trombe wall cannot avoid radiation of energy absorbed by the building into the outer environment because it lacks any heat insulation whatsoever.

- Lack of precautions in the summer - Another common failure is that the surfaces of the sunspaces, Trombe walls and air collectors contacting the outer environment are rigid; they cannot be opened during summer months. Hence, heated air sinks into the sunspace, causing undesirable rising temperatures inside. Also, sun breakers do not exist for sunny summer days, which would have avoided overheating glass surfaces intended for transferring solar energy into heat during winter months.

The cases under study are elaborated below.

\subsection{Features of the solar buildings sponsored by public institutions} 2.1.1 Middle East Technical University (METU) Solar House, Ankara. Construction specifications of the METU solar house.

The East and West walls consist of one row of brick $(20 \mathrm{~cm})$. No additional insulation material was used $\left(u=1.7 \mathrm{~W} / \mathrm{m}^{2} \mathrm{~K}\right)$. In addition to one row of brick, $10 \mathrm{~cm}$ gas concrete wall panels are used in the North wall following a $5 \mathrm{~cm}$ air cavity $\left(u=1.34 \mathrm{~W} / \mathrm{m}^{2} \mathrm{~K}\right)$. The North surface is completely made of glass and opens towards the sunspace, the roof of which is also made of glass $\left(u=2.58 \mathrm{~W} / \mathrm{m}^{2} \mathrm{~K}\right)$ (Figure 1).

Only the North wall is insulated, and no other precautions were taken. This design decision is at odds with the fundamental principle of "solid heating insulation" in a building heated by solar energy. In the main living space, a single glass window opens to a sunspace whose walls and roofs are glass. The building gathers heat for five hours per day and loses heat the remaining 19 hours. Most of the data about the building 
SS
28,5

\section{4}

Figure 1.

Schematic section drawing: sunspace of METU Solar House

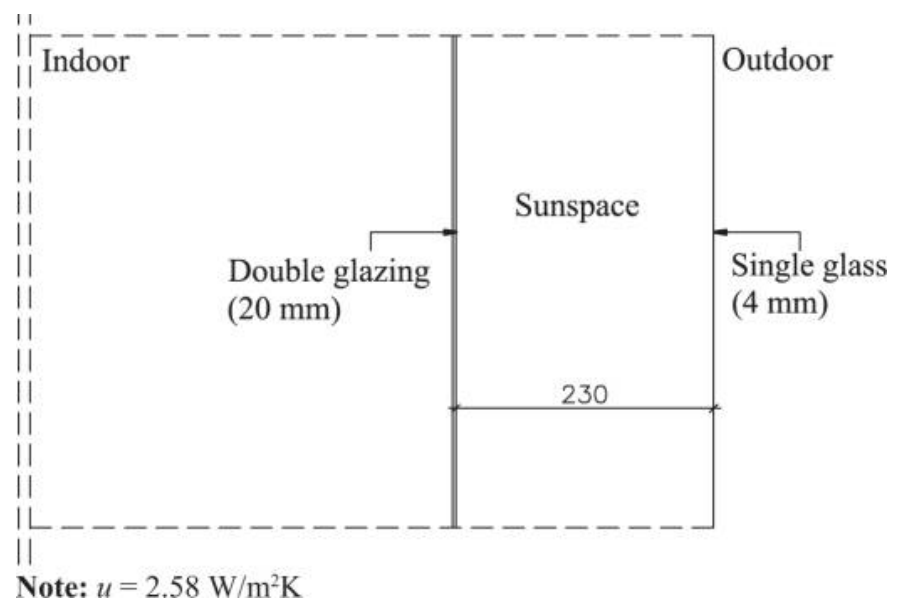

were gathered on site by the authors. Some data were obtained from ODTU. Research report No. 5 of January 1981 (Turan et al., 1981).

As observed from the illustration (Figure 1), the double glass wall shared by the living space and the sunspace is as long as the entire South surface, which is useless for thermal gain. Despite this fact, no preventive measures, such as an insulated sliding door or installation of Venetian blinds, were taken to avoid heat leakage from the living space to the sunspace during winter nights. Here, all exterior surfaces including the roof covering the sunspace are made of a fixed single glass cover. Because they cannot be opened or controlled like flexible, movable elements, the sunspace acts as a sunspace during the evenings in summer months. Hence, the house overheats during the summer, requiring the use of air conditioning and causing an increase in the energy used for cooling the living spaces that is greater than the savings on energy in winter using the sunspace.

2.1.2 Cukurova University Solar House, Adana. Construction specifications of the Cukurova solar house.

The East, West and North walls of the building are built of two rows of $9 \mathrm{~cm}$ hollow brick, and the $10 \mathrm{~cm}$ cavity between the rows is filled with $10 \mathrm{~cm}$ thick perlite $\left(u=0.43 \mathrm{~W} / \mathrm{m}^{2} \mathrm{~K}\right)$. The roof consists of a $10 \mathrm{~cm}$ concrete plaque covered with $10 \mathrm{~cm}$ perlite cement $\left(u=1.5 \mathrm{~W} / \mathrm{m}^{2} \mathrm{~K}\right)$. The floor does not have any heat insulation. The North wall consists of a $40 \mathrm{~cm}$ thick concrete wall, a $10 \mathrm{~cm}$ air cavity and a $4 \mathrm{~mm}$ single glass Trombe wall in front $\left(u=1.77 \mathrm{~W} / \mathrm{m}^{2} \mathrm{~K}\right)$ (Figure 2).

The glass surface is wood framed. The concrete behind it is painted black and causes overheating during the hotter seasons. In this case, no heat insulation was devised to prevent heat loss during winter nights, nor were protective measures taken to prevent the heat of the summer sun from penetrating the building. All the calculations about the building were provided from Altun (1982).

For reasons previously discussed, the Trombe wall, which composes almost all of the South façade, is a disadvantage during winter nights and cloudy winter days when compared with a heat-insulated ordinary outer wall in terms of resistance to heat transmission. Additionally, this massive wall causes undesirable heating of neighbouring spaces during summer months because it is neither movable nor 


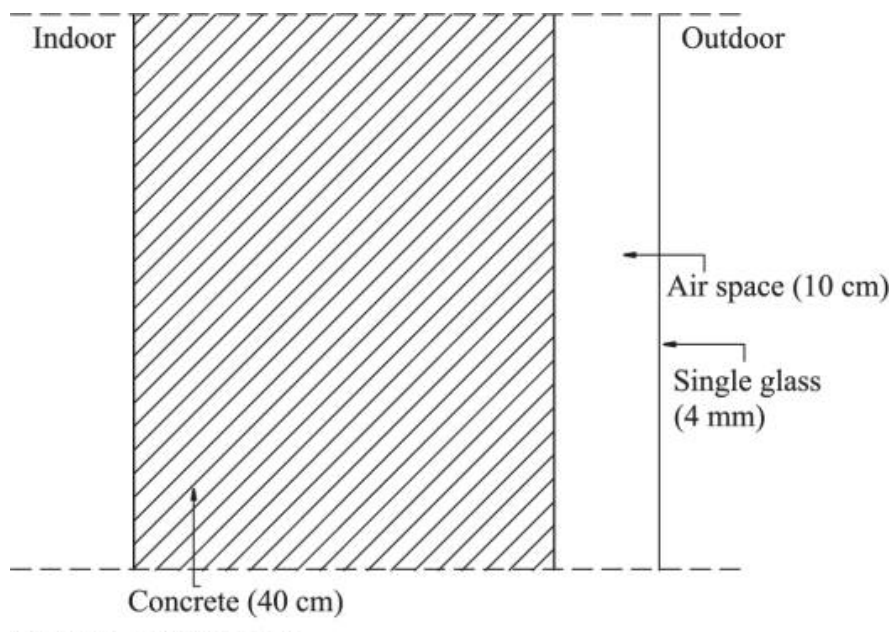

Malatya solar housing

Note: $u=1.77 \mathrm{~W} / \mathrm{m}^{2} \mathrm{~K}$

Figure 2.

Schematic section drawing: Trombe wall of Cukurova Solar House

pliable. Furthermore, Trombe walls because of their heavy weight masses are not good choices for multi-storey buildings in countries that might experience severe earthquakes. For these reasons, instead of Trombe walls, lightweight, heat-insulated air collectors would have been preferred.

2.1.3 BELKO Solar House, Ankara. Construction specifications of the BELKO solar house.

The east and west walls are made up of two rows of 9-cm thick hollow brick with a 10 -cm thick air cavity in between $\left(u=1.25 \mathrm{~W} / \mathrm{m}^{2} \mathrm{~K}\right)$. The floor has $5 \mathrm{~cm}$ thick glass wool (polystyrene insulation material) $\left(u=0.7 \mathrm{~W} / \mathrm{m}^{2} \mathrm{~K}\right)$ under $20 \mathrm{~cm}$ thick plain concrete. The ceiling consists of $10 \mathrm{~cm}$ glass wool on $10 \mathrm{~cm}$ thick reinforced concrete plaque and a tile roof $\left(u=1.48 \mathrm{~W} / \mathrm{m}^{2} \mathrm{~K}\right)$. The North and South sunspaces $\left(u=1.8 \mathrm{~W} / \mathrm{m}^{2} \mathrm{~K}\right)$ have double glass on the outside and inside. The office spaces have a $18.6 \mathrm{~m}^{2}$ window surface that opens towards the South sunspace and a $13 \mathrm{~m}^{2}$ window surface that opens towards the buffer zone located North (Figure 3).

The glass surface area that separates the sunspace and buffer area from the exterior is $46 \mathrm{~m}^{2}$. There is no precaution against heat loss via windows and glass during the evenings. Solar energy gathered via the sunspaces during a hot season creates an average of five hours of heating energy daily and loses heat during the remaining 19 hours. All data were obtained from on-site observations by the authors and calculations obtained from other researchers (Tan, 1993).

The idea of transmitting heat to the Northern units or to buffer zones via fans and pipes $20 \mathrm{~cm}$ in diameter is interesting and valuable. However, this application causes at minimum a $30 \mathrm{~cm}$ rise in the height of spaces. This principle is useful in creating buffer zones in the Northern elevation units of the building but fails to control the desired temperature in the Southern elevation units due to a lack of movable elements in the construction of the South façade, which is in direct contact with the outer weather. Hence, the interior is undesirably hot during the summer and causes heat loss during winter nights and cloudy winter days, as discussed above. 
SS

28,5

426

Figure 3.

Schematic section drawing: sunspace of BELKO Solar House

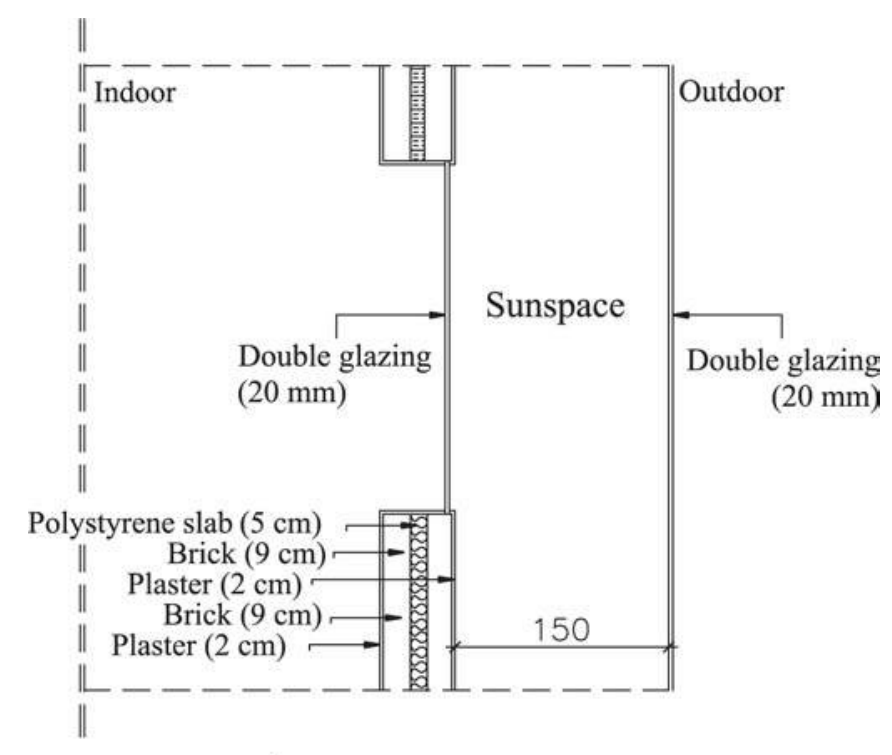

Note: $u=1.8 \mathrm{~W} / \mathrm{m}^{2} \mathrm{~K}$

2.1.4 Aegean University Solar Energy Institute, Izmir. Construction specifications of the AU solar house.

The East and West walls are $25 \mathrm{~cm}$ thick $(19 \mathrm{~cm}$ hollow brick + interior and exterior plaster) and have no heat insulation $\left(u=1.65 \mathrm{~W} / \mathrm{m}^{2} \mathrm{~K}\right)$. The north wall has $10 \mathrm{~cm}$ of perlite filling between a $20 \mathrm{~cm}$ thick reinforced concrete wall and a $20 \mathrm{~cm}$ thick cavity brick $\left(u=0.91 \mathrm{~W} / \mathrm{m}^{2} \mathrm{~K}\right)$ (Figure 4$)$.

No precaution was taken against heat loss from the sunspaces $\left(u=2.62 \mathrm{~W} / \mathrm{m}^{2} \mathrm{~K}\right)$, either during winter nights or against the transfer of exterior heat to the building during the summer months in this building. The building has neither air conditioning nor heating. In January, the average heat inside the building is $10^{\circ} \mathrm{C}$ in spaces that have no direct sunlight, such as halls and corridors, and $14^{\circ} \mathrm{C}$ in South-oriented spaces such as offices, classes, etc. In June, the average temperature in the hallways is $24^{\circ} \mathrm{C}$. An average temperature of $32^{\circ} \mathrm{C}$ has been recorded in South-facing spaces during this same month (Atagündüz, 1989).

This building, sponsored with great expectations by the president, prime minister and the head of the Higher Education Institute of Turkey in 1984-85, has posed the greatest impediment in the progress of solar architecture in Turkey due to the devastating disappointment it caused.

To summarise, the building failed because it consisted of a $60 \mathrm{~m}$ long and $11 \mathrm{~m}$ high concave single glass elevation facing South, where no precautions were taken against high summer temperatures, and no provisions were made against heat loss caused by induction of heat from inside to outside for winter nights and cloudy winter days.

Based on previous experience and information gathered from the observation of completed solar building projects, the first author of this article designed a privately developed residence, which was the first of its kind in Turkey, in this respect. 


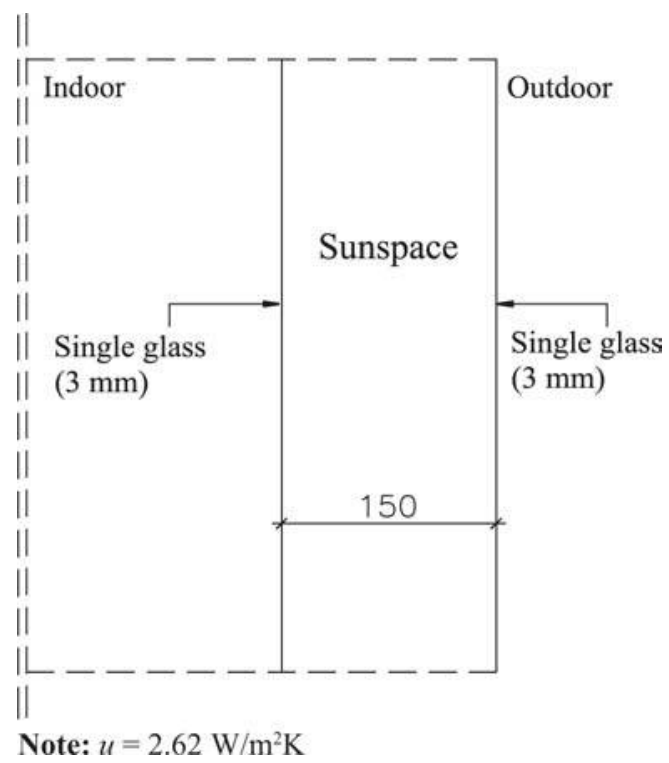

Malatya solar housing

Figure 4. Sunspace of AU Solar Energy Institute

2.2 Guzelbahce Solar House, Izmir

2.2.1 Construction specifications of the Guzelbahce Solar House (Plate 1). The walls consist of $25 \mathrm{~cm}$ gas concrete that contains insulation properties. A G4 product quality (a $\lambda \mathrm{R} 0.18 \mathrm{~W} / \mathrm{mK}$ product) $25 \times 60 \times 5 \mathrm{~cm}$ heat isolation plaque is used for other

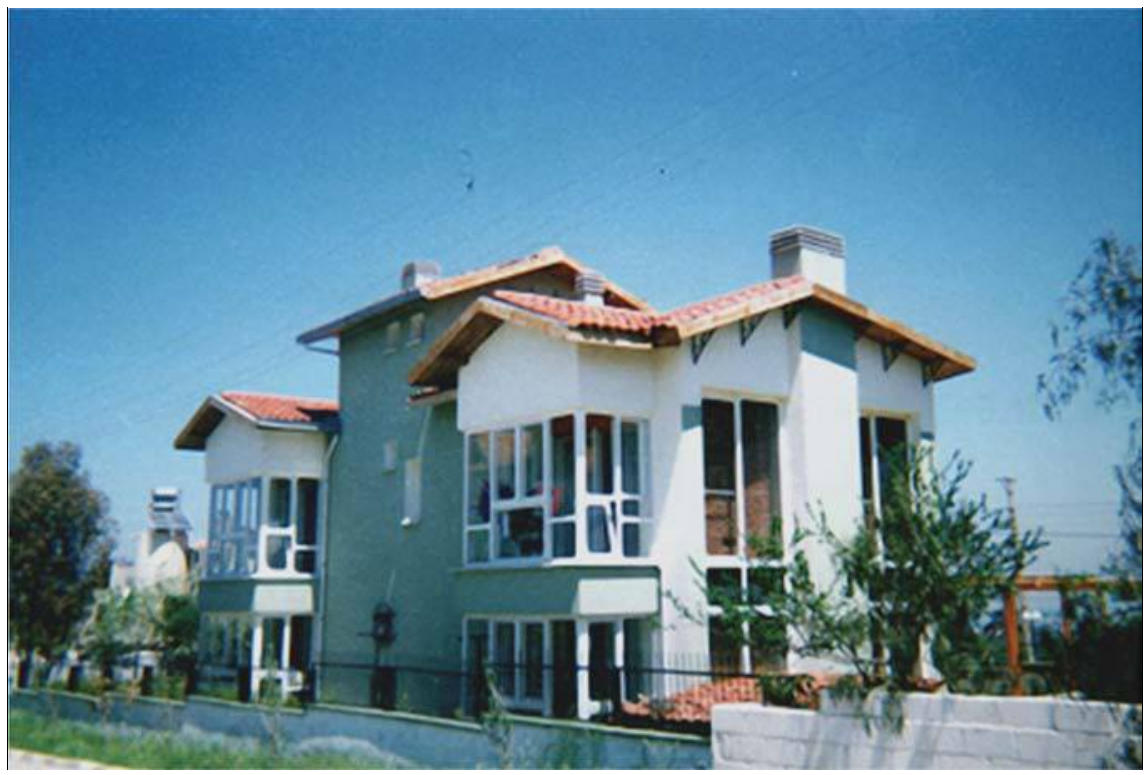

Plate 1. Guzelbahce Solar House 
SS

28,5

428

surfaces, such as exposed columns and beams. Six-centimetre long nails attach gas concrete insulation plaques to the interior surfaces of the scaffolding forming the exterior surfaces of the reinforced concrete slab.

Gas concrete insulation plaques are also nailed onto the internal face of the column scaffoldings before scaffolding wood is mounted to the columns that are exposed to exterior weather. The insulation plaque is stuck onto reinforced concrete during the casting process. This reduces the cost of workmanship that would have occurred during the building of scaffolding landing and gumming, which otherwise would have been stuck to the plaques after the reinforced concrete columns had been cast.

An area of $0.45 \times 0.65 \times 10.80 \mathrm{~m}$, which runs from the basement and ends $0.50 \mathrm{~m}$ above the roof ridge has been constructed next to an air chimney, which provides natural ventilation. Trombe walls and sunspaces are used for heating. All Trombe walls are laid with $5 \times 9 \times 19 \mathrm{~cm}$ solid bricks. To prevent surface dusting and to keep the emulsion of humidity and rain to a minimum, all the interior and exterior brick surfaces are coated with three layers of impregnable material for solid brick elements. Roller blinds are used against heat loss during winter nights and against exterior heat conduction in the summer.

On 3 July 2000 at $2.00 \mathrm{pm}$, the outside dry thermometer heat measured $34^{\circ} \mathrm{C}$ with a Westerly wind speed of $4.1 \mathrm{~m} / \mathrm{s}$ and a humidity value of 35 per cent. Inside the building in the living area $1.50 \mathrm{~m}$ above the ground, the temperature measured $28^{\circ} \mathrm{C}$. On 21 December 2000 at $9.00 \mathrm{pm}$, the living area temperature was $18.8^{\circ} \mathrm{C}$ while the outside temperature was $5.2^{\circ} \mathrm{C}$ (Okutucu, 2002).

In this unique solar housing project, predicated on the principle of avoiding the errors made in the preceding examples, heat lost from the sunspaces and walled surfaces during winter nights are reduced to $0.96 \mathrm{~W} / \mathrm{m}^{2} \mathrm{~K}$ by taking the following precautions:

- utilisation of double drapery inside;

- double-pane glass windows separating the sunspace from the inside;

- solid air preserved within the $5 \mathrm{~cm}$ cavity between a glass wall and heat insulated blinds;

- a single glass wall of sunspaces in contact with external weather; and

- $5 \mathrm{~cm}$ polystyrene material and $10 \mathrm{~cm}$ glass wool insulation covering the exposed surfaces of the floor and the ceiling of the sunspace.

Overheating of the sunspace is reduced by 80 per cent through the use of a folding single glass exterior surface, which also turns the sunspace into a balcony. The floor of the sunspace, which turns into a balcony during the summer months, blocks direct sunlight from penetrating the floor below, thus protecting the façade and preventing overheating of the façade during summer months. Four Trombe walls were built on the Southeast elevation of the house for this same reason. The glass faces of the Trombe walls were designed as sliding doors to avoid overheating and prevent heat transmission to adjacent spaces on especially hot days (Figure 5).

Starting in 1995 and for the following five years, a family of four lived in this solar house. Observations related to the resistance of the Trombe wall against heat during winter months were made by the architect (the first author) while measuring and evaluating this building (Okutucu, 2002). During this time, on the ground and first floors, the minimum temperature recorded was $16.1^{\circ} \mathrm{C}$, and the maximum high was 


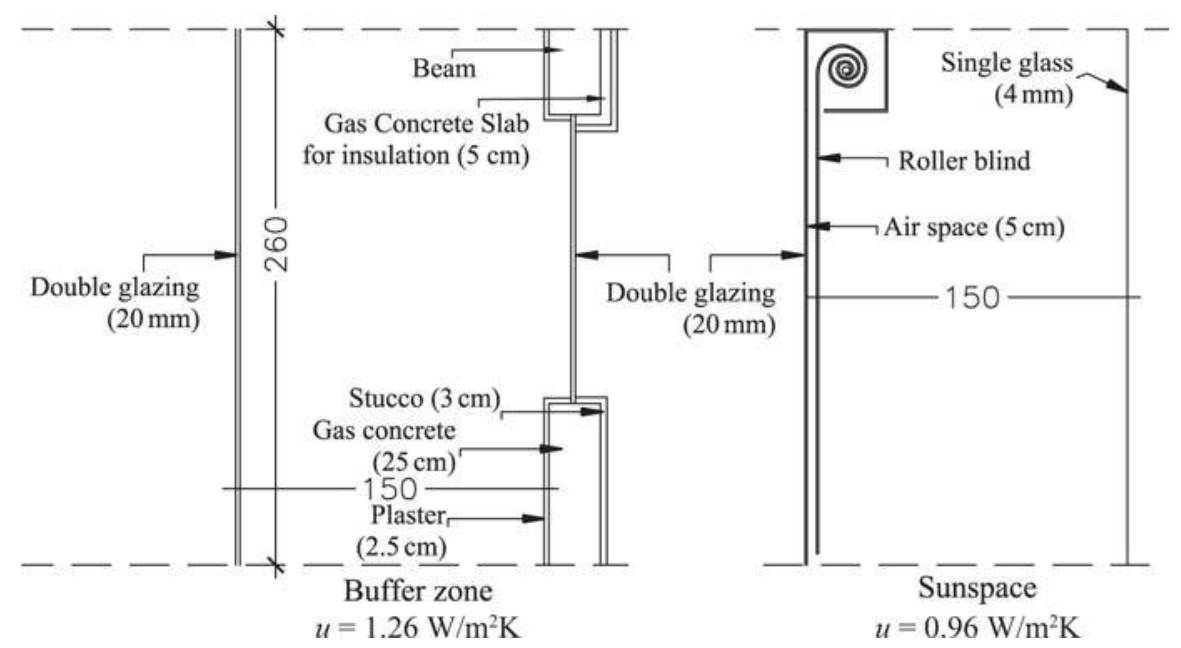
Malatya solar
housing

429

Figure 5.

Schematic section drawing: sunspace of Guzelbahce Solar House

$26.2^{\circ} \mathrm{C}$. The average temperature was $19.4^{\circ} \mathrm{C}$ with a five-year average usage of 157 litres of diesel per $146 \mathrm{~m}^{2}$ per season.

\section{Malatya Solar House}

Based on technical and practical knowledge gained from investigating passive solar energy principles applied in institutional buildings and the privately developed solar houses examined here, new assumptions were made to increase energy savings. These assumptions were provisioned in the design of another house, the Malatya Solar House. Scientific calculations cannot be performed before the house is built and put to use. However, it sets a good example as to how knowledge from practice can feed back into new attempts and how principles can be improved with regards to the faults depicted in previous examples. The exemplary building rendered below is meant to be understood by practising architects who wish to specialise in solar architecture. For this purpose, all calculations are deliberately omitted here. The main emphasis is on the conceptualisation of the house and the details that produce the desired results. The entire article is meant to encourage architects rather than limiting them with calculations. Furthermore, it should be emphasised that even with the required knowledge of calculations, the above mistakes were committed. Practice and the knowledge of detail are those that encourage perfection.

\subsection{Pre-design considerations}

Passive solar design can be defined as reducing energy consumption by combining the sun's energy with the local climate and building features to sustain thermal comfort conditions inside buildings (Rabah, 2005). In other words, energy consumption depends upon bioclimatic rule, the location of the building, continental climate and altitude (Tzikopoulos et al., 2005). Therefore, the first rule in heating buildings by passive solar energy is "correct orientation". To achieve this, the building has to be situated facing South or any Southward direction perpendicular to the established deviation angle of the particular Southern direction (Mingfang, 2002). For example, in Izmir, optimal solar exposure is achieved by having the wide facade of a building 
SS

28,5

430

facing a $17^{\circ}$ deviation from South to East. However, this is only possible if topography allows. If it does not, additional solar panelling should be used to compensate for the less than ideal orientation. Additionally, the building exterior is very important for passive systems because it can allow daylight to pass through to the interior for direct solar radiation and for fresh air throughout the building (Tombazis and Preuss, 2001).

There are two other important factors besides the orientation of the building in accordance with solar potential. For one, harmony of "earthquake movement direction" with the building is an issue. Demolishing a building is a menace to human lives and a waste of cement, brick, labour, furniture, etc. Thus, according to the authors, Turkey, a country located in a high-risk earthquake zone, should add "building an earthquake-safe building" to its list of requirements, which already includes designing for alternate energy sources (sun, wind, geothermal, efficiency, etc.)

For 9,000 years, earthquakes caused by the North Anatolian Fault Line have moved in the same direction. For earthquakes that move in a linear direction, rectangular buildings should be perpendicular to the fault line. However, in this case, the narrow side of the building would be facing South, which is less advantageous in terms of sun potential. To resolve this conflict between orientation and earthquakes, the building should be designed in a rectangle parallel to the fault line with earthquake dilatation, dividing the building into two squares.

Another important factor related to orientation is the surrounding scenery. If the direction of the scenery and the direction of the sun are at odds with each other than the solar energy obtained from the South facade may be directed towards the North façade via air channels and fans mounted on the floor and ceiling (Turan et al., 1981). For this solution, the floor height must be increased $25 \mathrm{~cm}$ and a suspended ceiling should span the entire ceiling. Further, the facades of buildings with this plan have to be very similar to each other. The electricity consumption and noise of fans are other potential disadvantages.

\subsection{Design features of Malatya Solar House}

3.2.1 Lift and staircase: considerations related to general massing. Main mass, form centre and the weight centre are located close to each other. Thus, the possibility of their twisting in an earthquake is minimised, thereby preventing damage to the building (Figures 6 and 7 and Table II). Via dilatation, the stairs and lift are separated from the isolated main mass, so that when inhabitants use the stairs or the lift, noise is minimised. The staircase functions like a chimney during a possible fire, thereby preventing it from spreading to upper floors. Because the main stairway has been designed as a fire stairwell, no other fire stairwells have been built.

3.2.2 Kitchen and bathroom. Main energy consumption in the buildings occurs in the kitchen and bathroom areas. By placing the kitchen and bathrooms in the centre of the building, excess heat produced from these spaces can be used to warm neighbouring areas.

3.2.3. Living area. The living area contains three contiguous walls and one long edge that opens to the South. The energy needed for heating this area is provided by sunspaces located on the East and West sides of the South facade of the building. Air collectors are located on the South facade, too.

3.2.4 Buffer zones. Windows play a significant role in the amount of the heat lost in the building via infiltration. Heat loss is greater in the North facade where the 


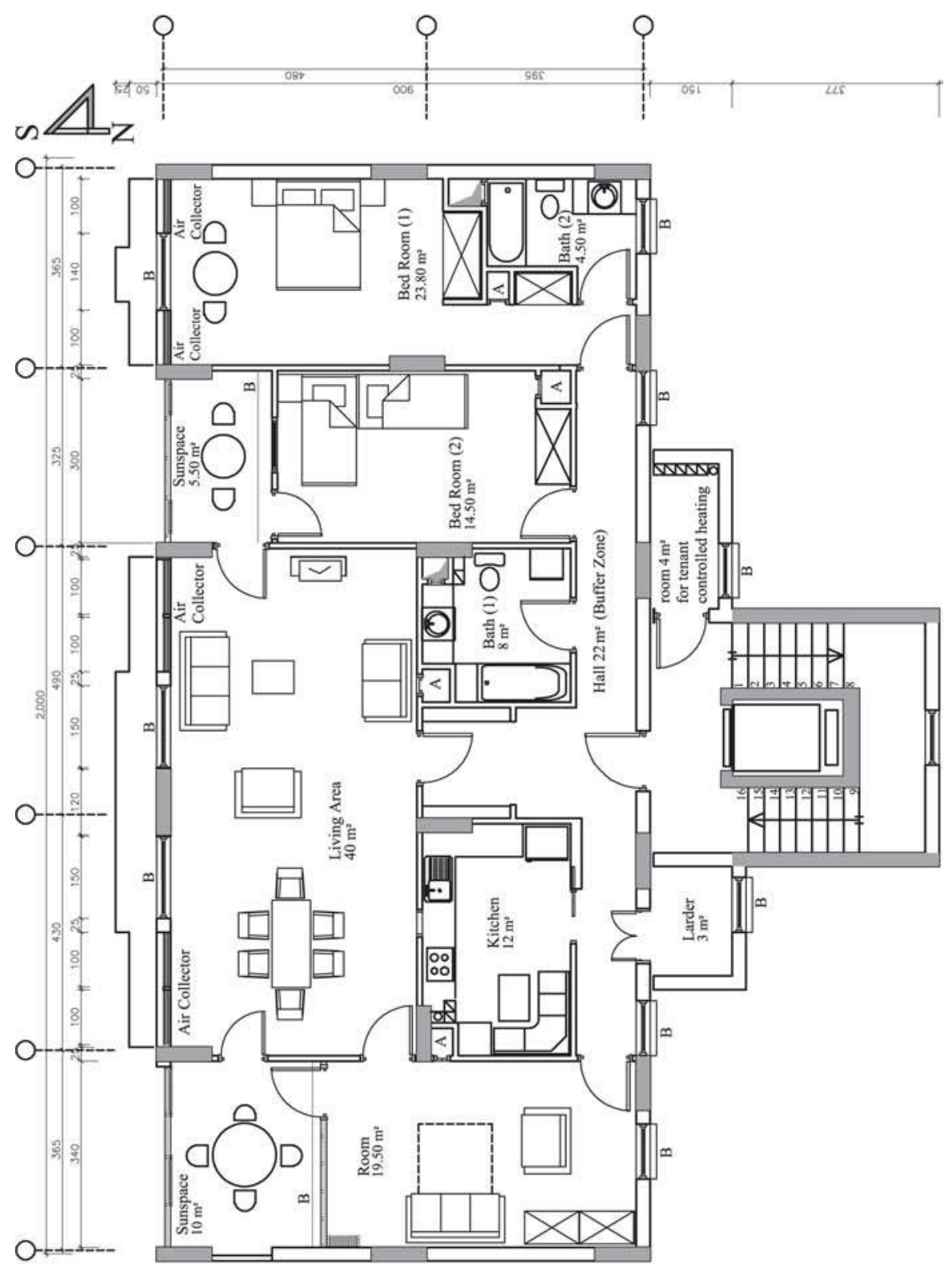

Malatya solar housing

431

Note: A: Ventilation chimney; B: Roller Blind

Figure 6. Ground floor plan of Malatya Solar House 
SS

28,5

432

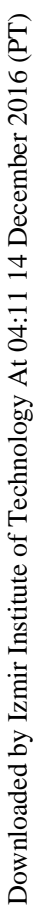

Figure 7.

South elevation of Malatya Solar House

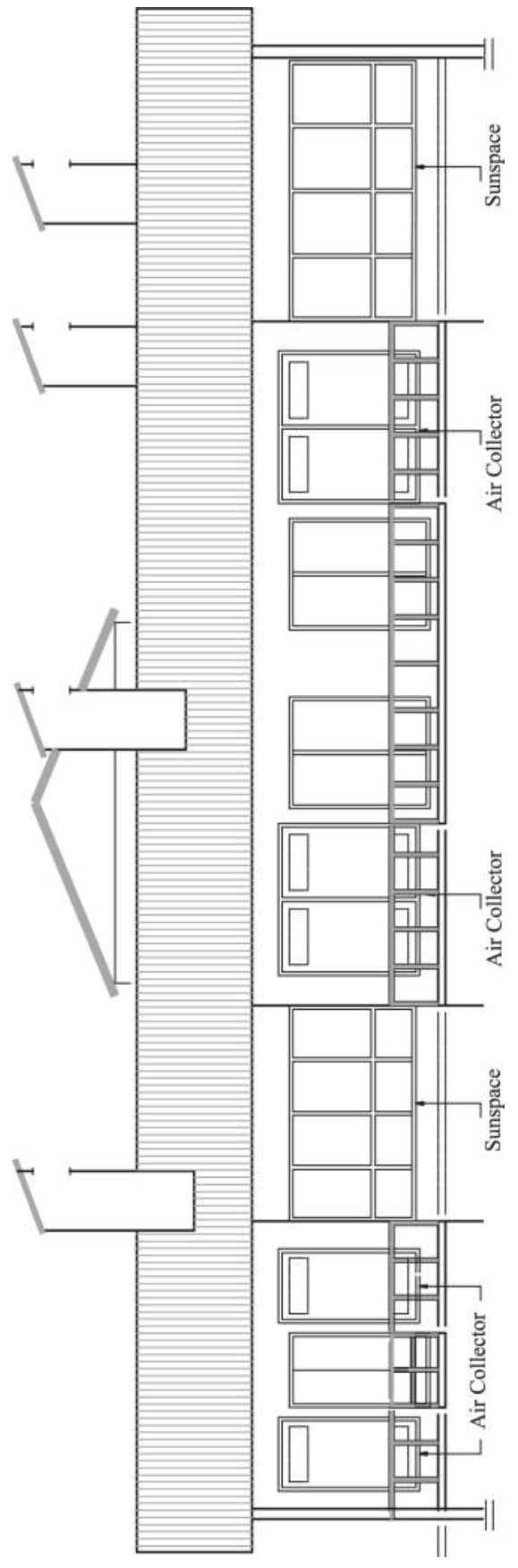




\begin{tabular}{lcrrr}
\hline & $\mathrm{m}^{2}$ & & $\begin{array}{r}\text { Malatya solar } \\
\text { housing }\end{array}$ \\
\cline { 1 - 2 } Total construction area & 191.60 & 517.30 & \\
Sun space & 15.50 & 41.85 & \\
Total heated area & 97.80 & 264.06 & \\
Buffer zone & 22.00 & 59.40 & $\mathbf{4 3 3}$ \\
Living area & 40.00 & 108.00 & \\
Room & 19.50 & 52.65 & \\
Bedroom (1) & 23.80 & 39.15 & \\
Bedroom (2) & 14.5 & 21.60 & \\
Bathroom (1) & 8.00 & 9.45 & \\
Bathroom (2) & 3.50 & 8.10 & \\
Cellar & 3.00 & 48.80 & \\
Room for tenant controlled heating & 4.00 & 53.50 & Some features of Malatya \\
Stairs and lift & 18.00 & & Solar House \\
Support system and walls & 19.80 & 13.80 & & \\
Total air collector & & &
\end{tabular}

difference between interior and exterior temperatures is at maximum. For this reason, the North windows of the Malatya Solar House open to the outside via buffer zones. Horizontal ventilation and cooling in the North-South direction is not entirely avoided but a lessening of scenery quality is expected in the Northern direction. In the plans of Malatya Solar House, because North windows belong to bedrooms and corridors, this will lessen the negative effect on the scenery. On the other hand, because a certain liberty will be gained in designing the North facade, a more plastic building will result.

3.2.5 South façade, sunspaces, and air collectors. The South façade is where the solar energy is converted into heat. The exterior surfaces of glass are comprised of two sunspaces measuring $6.40 \mathrm{~m}^{2}$ (Figure 7). Bedrooms are partitioned from the sunspace brow by folding doors made of double glass and by sliding doors. The positions of the air collector and sunspaces are illustrated in Figure 8. Their total surface area measures $16.70 \mathrm{~m}^{2}$. Insulated roller blinds $\left(u=0.96 \mathrm{~W} / \mathrm{m}^{2} \mathrm{~K}\right.$ are located $5 \mathrm{~cm}$ outside of these partitions. At night they reduce heat loss in sunspace areas. There are six, $2 \mathrm{~m}^{2}$ air collectors $\left(u=0.51 \mathrm{~W} / \mathrm{m}^{2} \mathrm{~K}\right)$ located in the South walls of the living area and main bedroom. Their vertical surface is $12.00 \mathrm{~m}^{2}$. After five years of observation and

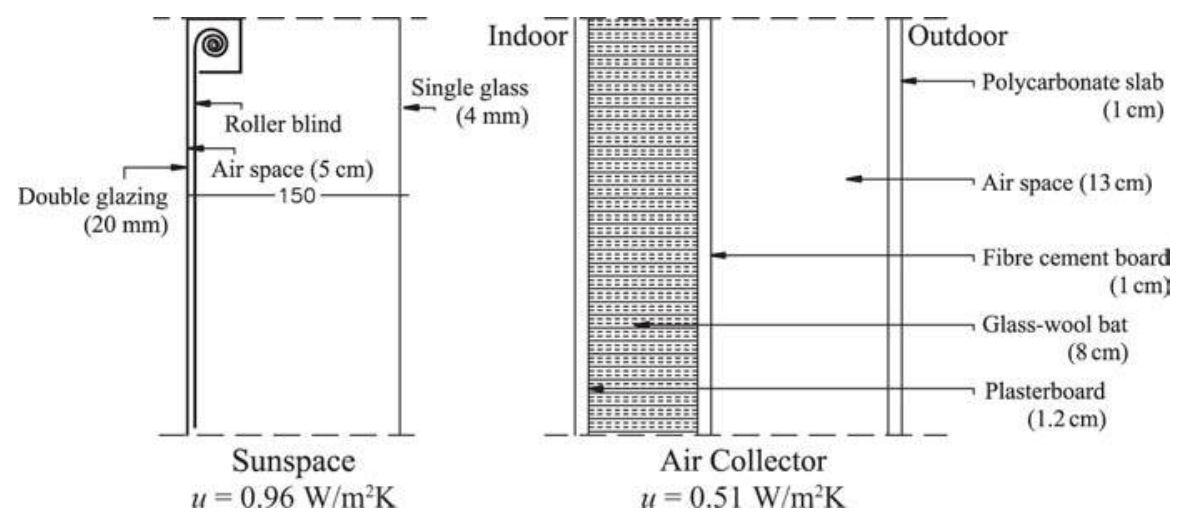

Figure 8.

Schematic section drawing: Sunspace and air collector of Malatya Solar

House 
SS

28,5

434

measuring the Guzelbahce Solar House, on average, a $1 \mathrm{~m}^{2}$ vertical collector surface (sunspace and Trombe wall) measures an energy of $167 \mathrm{kWh} / \mathrm{m}^{2}$ per heating season. A heating season is 5.5 months. This value, when multiplied by the $26.2 \mathrm{~m}^{2}$ total vertical collector area in the Malatya Solar House Project, shows that 4,375 KWh/heating season can be obtained.

\subsection{Natural ventilation}

In the nineteenth and twentieth centuries, people living in hot and dry climates constructed their buildings in "close configuration" in order take advantage of shadows provided by adjacent buildings. As a result, there is shade in months that require cooling. However, the close configuration lay-out prevents use of another important cooling element: the wind. As a solution, wind-capturing chimneys referred to as Windscoop, Malgaf or Badgir were built.

The working principle behind the chimneys replicates actual wind formation in nature. That is, the air movement (breeze/wind) between low-pressure areas and high-pressure areas is used for cooling the building. Air movement during the cooling season moves from the interior of the building towards the exterior during the day and from the exterior towards the interior during the night. Adequate passive ventilation can also be provided by way of a solar-heated element for one-storey buildings (Letan et al., 2003). Modern cities are almost always built according to "close configuration" for economical or cultural reasons. As a result, regional winds have not been used to full advantage. The Guzelbahce Solar House designed and constructed in 1994 and wind holders constructed in offices at the Aegean University Solar Institute are two examples of buildings that utilise regional winds in their interiors for cooling purposes and air movement inside the buildings on windless days. Observations and knowledge gathered from these two examples were applied in designing the Malatya Solar House (Figures 9-11).

\subsection{Energy estimates for Malatya Solar House}

One of the most important design decisions in the proposed solar house was whether to use buffer zones throughout the Northern wall. The necessary amount of energy needed for heating, both with and without a buffer zone per season is given below.

\subsubsection{With a buffer zone}

- Energy needed for heating = established hourly energy need in anuary given an outside temperature of $8^{\circ} \mathrm{C} \times 16$ hours $\times$ number of days in which seasonal heating is necessary for Izmir.

- Energy needed for heating $\times 4,404$ Wh $\times 16$ hours $\times 116$ days $=8,173$ $\mathrm{kWh} /$ season.

3.4.2 Without a buffer zone. Energy needed for heating $=5,495 \mathrm{Wh} \times 116$ days $\times 16$ hours $=10,198 \mathrm{kWh} /$ season. Proportional differences between these two cases $=10,198 \mathrm{kWh} /$ season $-8,173 \mathrm{kWh} /$ season $=2,025 \mathrm{kWh} /$ season.

The amount of required heating energy provided from the sun for a building with a buffer zone is calculated below:

- Energy provided by the sun in the proposed solar house = total vertical collector surface area of house $\times$ five of energy year average of the amount obtained from the vertical collector surfaces of the Izmir Guzelbahce Solar House in one year average of the amount heating season $(116 \times 16$ hours $)$. 


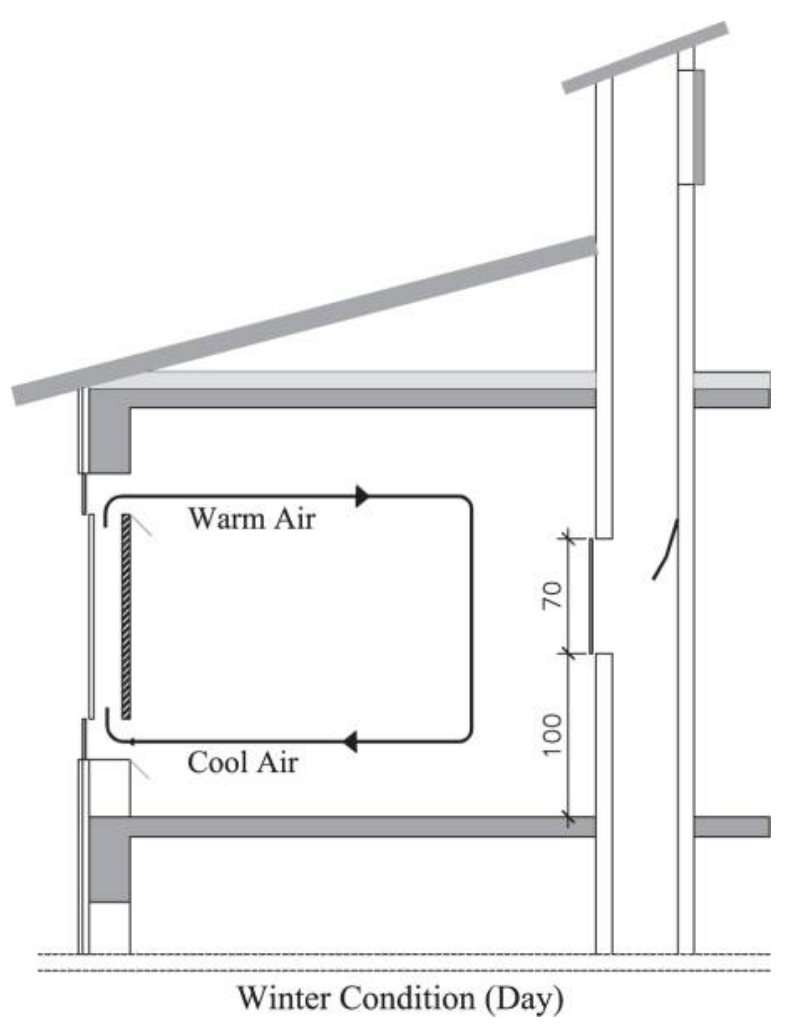

\section{Malatya solar housing}

435

Figure 9. Schematic section drawing: Natural ventilation of Malatya Solar House

- Energy provided by the sun in the proposed solar house $=26.2 \mathrm{~m}^{2} \times 167$ $\mathrm{kWh} /$ season $=4,375 \mathrm{kWh} /$ season.

Additional energy needed for heating $=$ total energy needed for heating - heating energy provided by the sun.

Additional energy needed for heating $=8,173 \mathrm{kWh} /$ season $-4,375 \mathrm{kWh} /$ season $=$ $3,798 \mathrm{kWh} /$ season. To put it differently, 53 per cent of the energy needed for heating can be obtained from the sun. The rest of the required energy can be obtained as follows:

- From electricity: $3,798 \mathrm{kWh} / \mathrm{season} \times \$ 0.12 / \mathrm{kWh}=\$ 455 /$ season (fixed price for $1 \mathrm{kWh}$ electricity per apartment including taxes).

- From coal: $3,798 \mathrm{kWh} /$ season $=0.6$ ton coal $\times \$ 106 /$ ton $\$ 67 /$ season (fixed price for 1 ton coal including taxes).

- From diesel: $3,798 \mathrm{kWh} / \mathrm{season}=320$ litres fuel oil $\times \$ 1.66 /$ litre $=\$ 531 /$ season.

In evaluating the cooling quality of the proposed solar house according to estimates based on observations and measurements in the Guzelbahce Solar house and Murat Reis Library (another building designed by the first author) in the cooling seasons, it 
SS

28,5

436

Figure 10.

Schematic section drawing: Natural ventilation of Malatya Solar House

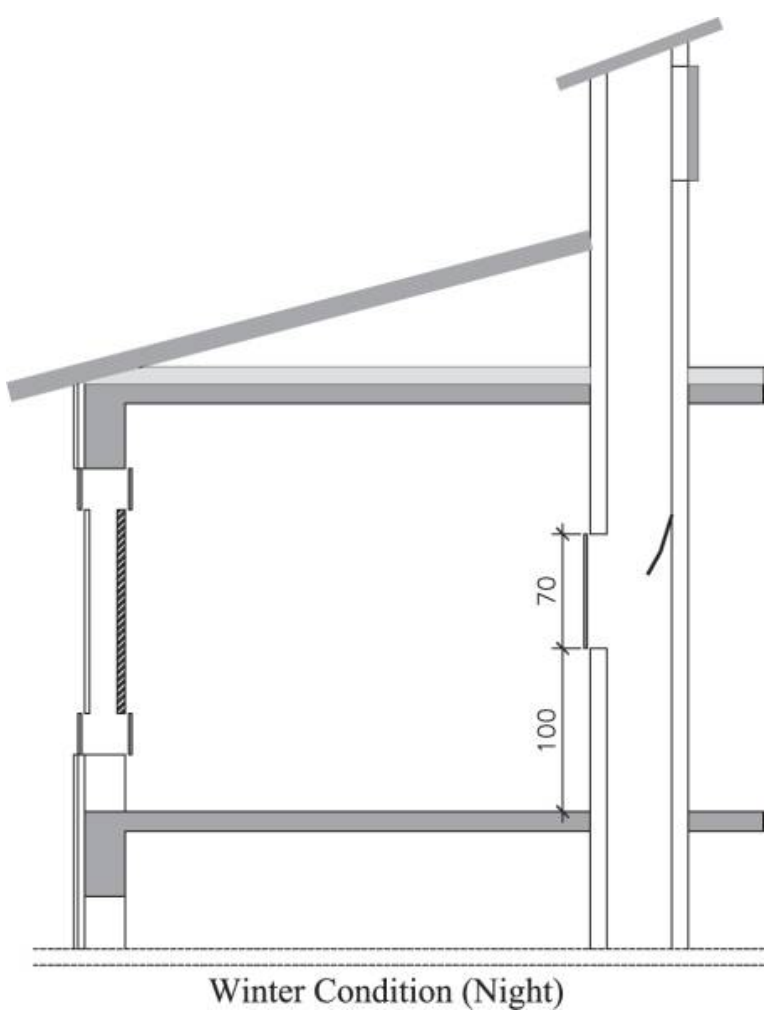

can be assumed that during between 12.00 and 14.00 interior temperatures will be $6^{\circ} \mathrm{C}$ below the outside temperature.

\section{Conclusions}

This article has examined practical applications of solar design and architecture of existing buildings throughout Turkey. This study considers how, in the process of researching as a practical application of accumulating knowledge, the results of can be adopted and applied to future projects.

On one level, this can be seen as a historical project in that when someone extracts potential knowledge embodied in and enacted through a historical object, one recreates what was (even unconsciously) achieved through it. However, we prefer to wager that the above examples can also be read experimentally as in this article.

Methodologically, this has obvious relevance to securing research-by-practice as indeed a research (i.e. a knowledge producing) activity. Part of the interest in this exercise was to see how one might access this knowledge and apply it practically. This is, after all, an exercise in making things intelligible: a work of translation to be sure, and a work requiring a sensitivity to the object itself, because the entire point of the process here is to bring the object to "speak" in a way that it is capable not only of being interpreted within given or current intellectual contexts but grasped in terms of what it itself offers to knowledge (Dilnot, 2006). 


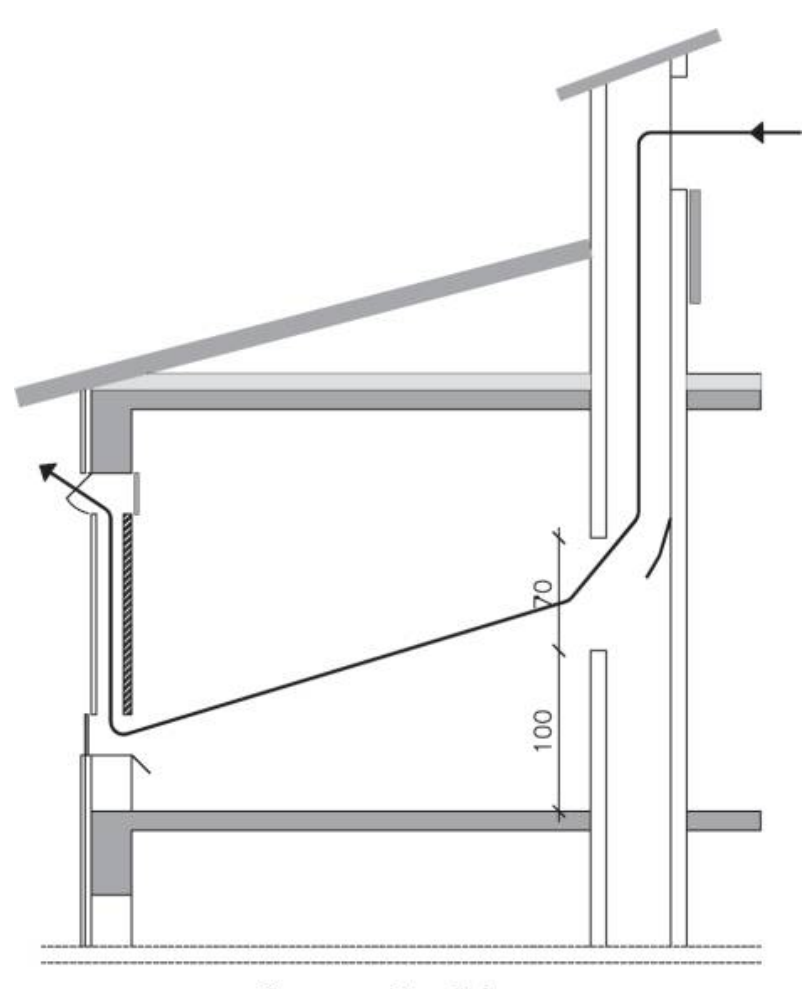

Summer Condition
Malatya solar housing

437

Figure 11.

Schematic section drawing: Natural ventilation of Malatya Solar House

We know that the difficulty in design as a whole, intellectually, is being able to create in the physical world what is visualised in the mind. This problem is doubled for design research where creating such visibility is of the essence. The difficulty for design researchers is how to establish the intellectual frameworks in which to do this.

The desire to use original creations and works is precisely what design researchers offer, either in terms of their practical work (in whatever dimensions) and/or in terms of their cognitive content. Such works force descriptive attention (Dilnot, 2006). This is valuable methodologically because it works against the interpretive tendency, forcing attention not on the interpreter's cognitive model but on the configurative and dispositional features of the thing itself. This is where the difference between interpretation in other artistic fields and interpretation in design practice lies. Generally, hermeneutics focus on writer/reader dilemmas and argue the relativity of ideas and values of the author and the audience, whereas practice-based research in design disciplines such as solar architecture is beyond relativity; here the success of design is predicated upon expected net outcomes of the system, performance, longevity, etc. Impartiality of interpretation is safeguarded by the criteria of evaluation based on measurements and calculations that are compared with an ideal, and this is exactly what this article has undertaken.

The intellectual framework (the interpretative tool) defined in the article is simple: neither ambiguous nor complicated. The calculations in the process of this research are deliberately omitted in the text. Rather, the visuals are emphasised. Engineers can 
SS

28,5

438 easily carry out computations. Here, we have emphasise the details and reasons for the solar project failures as extracted from the research.

Some positivists may insist that the conclusions drawn from practice research do not represent true knowledge (which even often science fails to guarantee) because neither scientific methodologies nor empirical methods are employed in such research. However, knowing the refinements in practice and when and why they are realised improves know-how and is adopted into theory. Even congresses have realised there is a serious need to disseminate knowledge extracted from practice - for example Research into Practice Conference was held on 31 October 2008 at the Royal Society of Arts, London.

Practice is a trial-and-error area where scientific information is scrutinised and fed back into the building up of theoretical knowledge. However, practitioners seldom get a chance to share their practical and practice-based experiences and information with others because they believe that the information they yield is irrelevant. Technocrats of science-based knowledge, especially practising architects, are seldom invited for lectures or conferences as opposed to the "star" academicians and "star" architects. The few people who show interest in their expertise are usually the producers and marketers of building materials. Hence, the knowledge gained from the application of sciences remains unnoticed, particularly in the field of architecture. Consequently, every time someone new in the field steps forward to experiment in building sciences, they are forced to start from scratch. This is a major setback in knowledge sharing which in turn delays scrutinising new theories. Such practices as those cited in this article require years of close observation, investigation and personal judgement; the subject itself is vital. Sustainability guarantees the subsistence of future generations. Therefore, herewith we share.

\section{References}

Ackoff, R.L., Gupta, S.K. and Minas, J.S. (1962), Scientific Research. Optimizing Applied Research Decisions, Wiley, New York, NY.

Altun, Z.G. (1982), "Çukurova Bölgesi Koşullarında Edilgen Günes Evi Denemesi ve Parametrelerinin Belirlenmesi”, ("A passive solar house experiment in Çukurova Region and determination of its parameters"), unpublished Master's thesis, Cukurova University, Adana.

Atagündüz, G. (1989), Gunes Enerjisi Temelleri ve Uygulamalari, Compiled Essays (The Basics of Solar Energy and Practice), Ege Universitesi Gunes Enerjisi Enstitusu Yayinlari, İzmir, pp. 201-14.

Aydan, U. (2010), "Liquid fuel prices and taxes in Turkey and USA", available at: www.dektmk. org.tr/upresimler/Turkiye (accessed 7 November 2010).

Dilnot, C. (2006), "Knowledge from practice: creating the intellectual context", Research into Practice Conference, University of Hertfordshire, selected abstracts, pp. 17-18, available at: http://citeseerx.ist.psu.edu/viewdoc/download?doi=10.1.1.136.4040 (accessed 8 July 2010).

Feyerabend, P. (1975), Against Method, Verso, London.

Feyerabend, P. (1987), Farewell to Reason, Verso, London.

Karakoc, T.H. (2006), KTH Kalorifer Tesisati Hesabi, Demir Dokum, Istanbul.

Kiraly, J. (1984), Architektur mit der Sone, C.F. Müller, Karlsruhe. 
Letan, R., Dubovsky, V. and Ziskind, G. (2003), "Passive ventilation and heating by natural convection in a multi-storey building", Building and Environment, Vol. 38 No. 2, pp. 197-208.

Mingfang, T. (2002), "Solar control for buildings", Building and Environment, Vol. 37 No. 7 , pp. 659-64.

Okutucu, F. (2002), "Pasif Gunes Enerjisi ile Isitılan Yapilarda Optimizasyon: Boyutlar ve Maliyet", ("Optimization in buildings heated by passive solar energy: magnitudes and costs"), unpublished dissertation, Karadeniz Technical University, Trabzon.

Okutucu, F. (2007), “Guzelbahce Gunesevi”, Tasarim, Vol. 4, pp. 134-5.

Özdeniz, B.M. (1984), Yapı Tasarm için Türkiye İklim Verileri, KTU, Trabzon.

Rabah, K. (2005), "Development of energy-efficient passive solar building design in Nicosia, Cyprus”, Renewable Energy, Vol. 30 No. 6, pp. 937-56.

Tan, M. (1993), "New technologies to provide efficient and wider use of renewable energies in cities: the case of Ankara", paper presented at the OECD Workshop on Renewable Energies and the Urban Environment, Ankara.

Tombazis, A.N. and Preuss, S.A. (2001), "Design of passive solar buildings in urban areas", Solar Energy, Vol. 70 No. 3, pp. 311-18.

Turan, M., Ecevit, A., Gürdil, F.I. and Mutaf, G. (1981), Güneş Evi. Mimarlk Fakültesinde Bir Deneme (Solar House. An experiment at the Faculty of Architecture), Research Report 5, Middle East Technical University Press, Ankara.

Tzikopoulos, A.F., Karatza, M.C. and Paravantis, J.A. (2005), "Modelling energy efficiency of bioclimatic buildings", Energy and Buildings, Vol. 37 No. 5, pp. 529-44.

To purchase reprints of this article please e-mail: reprints@emeraldinsight.com Or visit our web site for further details: www.emeraldinsight.com/reprints 
This article has been cited by:

1. Aurora Monge-Barrio, Ana Sánchez-Ostiz. 2015. Energy efficiency and thermal behaviour of attached sunspaces, in the residential architecture in Spain. Summer Conditions. Energy and Buildings 108, 244-256. [CrossRef]

2. Shiv Lal Center for Energy Studies, Indian Institute of Technology Delhi, New Delhi, India S.C. Kaushik Center for Energy Studies, Indian Institute of Technology Delhi, New Delhi, India P.K. Bhargava Department of Energy and Building, Central Building Research Institute Roorkee, Roorkee, India . 2013. A case study on solar chimney-assisted ventilation for residential building in India. International Journal of Energy Sector Management 7:4, 478-490. [Abstract] [Full Text] [PDF] 